\title{
A Study on Construction Strategy of Formative Evaluation in Higher Vocational English Teaching
}

\author{
Li Tianyi \\ Foreign Language Department \\ Jilin Business and Technology College \\ Changchun, China \\ 182076127@qq.com
}

\begin{abstract}
Teaching and teaching evaluation are inextricably linked and the scientific system of teaching evaluation can evaluate students' English ability and teachers' teaching quality so as to provide scientific guidance for improving teaching quality. Nowadays, the English teaching evaluation system is not comprehensive enough in most vocational colleges, which can not fully reflect the students' English ability and teachers' teaching effect. In this thesis, the current situation for the application of formative evaluation in higher vocational English teaching is expounded and the strategies for the construction and application of formative evaluation in higher vocational English teaching are put forward.
\end{abstract}

Keywords-Formative Evaluation; Higher Vocational English Teaching; Current Situation; Principle

With the students' final exam results as the evaluation criterion and basis, the higher vocational English teaching evaluation is not comprehensive and objective. The formative evaluation method put forward in this thesis highlights the principal status of student and scientifically evaluate the learning condition of student. The formative evaluation method can improve the students' comprehensive quality and lay a solid foundation for their future development.

\section{CONNOTATION OF FORMATIVE EVALUATION THEORY IN HIGHER VOCATIONAL ENGLISH TEACHING}

The formative evaluation theory in higher vocational English teaching refers to the systematic evaluation on the curriculum development of higher vocational colleges, the teaching situations of English teachers in higher vocational colleges and the learning conditions of students in higher vocational colleges; the purpose for using systematic evaluation in higher vocational English teaching is to enhance the teaching quality of English teachers in higher vocational colleges and cultivate the practical and creative abilities of students during the learning process.[1] The principle of formative evaluation is to assist in the course arrangement and teaching of English teachers in higher vocational colleges. What calls for attention is that the formative evaluation finds the parts the teachers and students should enhance attention through evaluation system instead of stage treatment so as to give play to the learning initiative and enthusiasm of students in higher vocational colleges.

The formative evaluation is different from the summative assessment which is only conducted at the end of terms instead of running through the whole teaching and learning process of teachers and students in higher vocational colleges. The purpose of summative assessment is to divide the students into different grades and to evaluate the students' abilities through English examination results so as to generalize and evaluate the learning status of students. With stronger reliability, the summative assessment plays an irreplaceable role in student evaluation.

\section{DeVElopment Situation of EVAluation System of HighER VOCATIONAL ENGLISH TEACHING}

At present, the higher vocational English teaching evaluation lays particular emphasis on the examination of students' grasping condition of English knowledge as well as the ability to use English knowledge; however, there are few evaluations on the student performance and attitude during the English learning process. Compared with the exam results, the innovation and exploration of English learning method have not attracted too much attention; moreover, it is thought that the academic achievement represents everything. The evaluation of Chinese higher vocational education thinks highly of results; if a student obtains good results, he is deemed to be perfect in every aspect, which is not the case. The academic record can't represent everything and can't reflect the student's learning ability, learning attitude and initiative spirit. Currently, the evaluation system of higher vocational English teaching only includes evaluation on English final examination performance, evaluation on English mid-term examination performance and evaluation on other English examination performance, which can't comprehensively evaluate the student's English learning ability; hence, the English exam results can only explain the mastery degree of English knowledge as well as the test-taking ability of the student instead of accurately evaluating the English competence of the student; due to such evaluation system, the students in higher vocational colleges begin to attach importance to English examination performance and make no effort to explore learning methods and change learning attitude. To make matters worse, some students in higher vocational colleges boycott learning English. [2]Without the pressure in senior high school entrance examination and college entrance examination, the students in higher vocational colleges should focus on the application of language so as to have a good command of a foreign language an improve verbal communication ability. The formative evaluation covers many 
aspects in higher vocational English teaching, which can effectively improve the student's listening, speaking, reading and writing skills. The formative evaluation aims to make the student get a comprehensive understanding of the learning situation instead of dividing the students into grades. The formative evaluation is a two-way evaluation of teaching and learning and it refers to the mutual evaluation between teachers and students and between schoolmates, which covers the whole English learning process and endeavors to exploit the potential of every student. During the teaching process, the English teachers in higher vocational colleges can not only directly observe and inquire about the students' feelings and the difficulties, but also realize the students' English learning situation through indirect modes, such as mutual evaluation between students or questionnaire survey.

\section{NECESSITY OF FORMATIVE EVALUATION IN HigHER VOCATIONAL ENGLISH EDUCATION}

The purpose of modern education evaluation is changing constantly and attaches importance to the all-around evaluation. Along with the constant deepening of task-based classroom teaching in higher vocational English teaching, the formative evaluation will gradually replace the old evaluation method and be applied in the Chinese educational field. The higher vocational English education imports modern computer technology which will assist in the improvement of the evaluation condition of English language teaching in higher vocational colleges. Under the new historical background and social need, the higher vocational colleges should actively introduce the advanced evaluation system so as to evaluate the learning condition of students in higher vocational colleges from full range and different levels.[3]If the traditional summative assessment is used continuously, it will have a negative effect on higher vocational English teaching.

The formative evaluation in higher vocational English teaching can help the vocational school teachers cultivate the students' English competence according to the social requirements on talents. The formative evaluation results can provide references for the teachers and students; the students can make up for the learning deficiency through the evaluation results as well as improve the learning method and the teachers can be aware of the students' development situations, guide the students to learn and reflect and correct deviation. There is close relationship between the appraiser and the object being evaluated. The formative evaluation is conducted during the learning and teaching process, which is different from the common mid-term examination evaluation, final examination evaluation and entrance examination evaluation; the formative evaluation can help the vocational school teachers discover the difficulties students meet during English learning process and offer the targeted solutions and guidance according to the different difficulties; moreover, it can help students in higher vocational colleges develop self-confidence during English learning process and explore innovation interest and ability. The evaluation methods and ideologies in formative evaluation system can be the reflection of educational progress and age progress, which is beneficial to the students' integrated development.
The formative evaluation is introduced to higher vocational English education, which can comprehensively evaluate English learning ability and condition of student in secondary vocational school and bring benefits to the students in the long run. The objects of formative evaluation should not be confined to English knowledge; instead, the English skills, learning methods and learning attitude should be incorporated and the comprehension on different cultures should be deepened. In higher vocational English teaching, the subjective initiative of teachers and students should be exerted so that they can take the initiative to help the students with learning difficulties. The essence of formative evaluation is to take the English teachers and students in higher vocational colleges as the decision makers who can make decisions according to the continuous data obtained during the teaching and learning process; in other words, the teacher should adjust teaching schemes and the students should improve learning attitudes and methods.

\section{Application Principles of Formative EVAluation IN HigHER VOCATIONAL ENGLISH TEACHING}

\section{A. Subjectivity Principle of Formative Evaluation}

The subjects of formative evaluation in English language teaching of higher vocational colleges include not only the English teachers but also the students; the principal status of students can help them arise the motivation during English learning process so that they can have the sense of responsibility as well as sense of mission that can help improving the students' English learning ability. The students in higher vocational colleges have been equipped with mature mind and independent thinking ability; therefore, they should be given the self-development space and the opportunity to evaluate their own learning situations so as to grasp the learning status. Through the evaluation results, the students can be aware of the advantages and disadvantages, make full use of the advantages and seek for methods to offset disadvantages so as to improve themselves. The subjectivity principle requires the students in higher vocational schools to bring the subjective initiative into play, learn actively to be the masters of learning and develop good learning habits. The teacher should change traditional ideas to form student-oriented teaching management model and positively guide the students to participate in teaching evaluation [4].

\section{B. Multiplication Principle of Formative Evaluation}

In the assessment process of higher vocational English teaching, the following four parts should be studied and tried when applying and following the multiplication principle.

The first one is the diversification of formative evaluation method. During the higher vocational English teaching evaluation process, there are several methods for the teachers and students to apply, such as direct observation and inquiry as well as indirect test. For the higher vocational schools, the pencil-and-paper test is a traditional evaluation method for mid-term examination, final examination or application ability examination and part of its contents can be used for reference when applying formative evaluation. The pencil-and-paper test is convenient and fast and it is easy to evaluate the test results, however, there are certain shortcomings. For the higher 
vocational English teaching, it is required that the students should master language knowledge and skills as well as possess verbal communicative competence. With limitations, the pencil-and-paper test can't test the student's verbal communicative competence and thus the obtained result can not represent the real language competence. For the formative evaluation of higher vocational English teaching, the students and teachers can choose from many methods; for example, the student can choose the mutual evaluation between schoolmates so that the evaluation can be more objective and the teachers can evaluate the whole learning process so that the evaluation results can be more comprehensive or adopt small test so as to evaluate the learning condition of students on certain knowledge. [5]

The second one is the diversification of evaluation subject. The formative evaluation in higher vocational English teaching can conduct a more effective evaluation on the English learning condition of students in higher vocational colleges because the evaluation subjects include not only the teachers but also the students, parents and the whole society who can give different appraisals on the basis of the personal emphases so that the students can get a comprehensive understanding of themselves. In the evaluation process, the students become the evaluation subjects and thus they can integrate into the evaluation and find their merits and demerits through the evaluations between students and between teachers and students so that they can conduct self-reflection, self-education and self-examination. Such evaluation method with multiple subjects and directions can not only make the students in higher vocational colleges realize the learning condition during the English learning process so as to seek for solution and developing direction, but also build up the students' thinking abilities and communication abilities, which can be favorable for the development of students in higher vocational colleges.

The third one is the diversification of evaluation content. The contents of formative evaluation in higher vocational English teaching are many-sided and all-around, including the English learning condition, understanding level, classroom participation degree, individual value orientation and values. The evaluation elements of formative evaluation should be complete and scientific and thus attention should be paid to not only the evaluation on the student's master condition of English knowledge points but also on the learning attitudes, learning methods and inner reflections of students in higher vocational colleges.

The fourth one is the diversification of evaluation standard. The diversification of formative evaluation standard means that the evaluation on higher vocational English teaching can be both transverse and longitudinal; for the transverse evaluation, the evaluation standard can be the program objective, that is to evaluate the completion condition of program objective when evaluating the students in higher vocational colleges; moreover, through the integration of transverse evaluation with longitudinal evaluation, the comprehensiveness and hierarchy of evaluation results can be guaranteed. In addition, the evaluation standard for the evaluation system of higher vocational English teaching can also be the intellectual development, comprehension of cultures, world view and moral quality. Such critical points and key factors should be evaluated and measured through the formative evaluation system during the evaluation process of higher vocational English teaching. It is worth noting that the evaluation of higher vocational English teaching is a kind of statistical work that should be done through qualitative analysis as well as quantitative analysis so that the results can be convincing; In this case, the students and teachers in higher vocational colleges can think highly of and have confidence in it so that it can help the students find ways to solve learning problems and the teachers formulate the targeted teaching schemes. In addition, during the evaluation process of higher vocational English teaching, the teachers should attach importance to the influence of enthusiasm evaluation on students in higher vocational colleges so as to reserve the most meaningful and valuable contents in English language teaching.[6]

\section{Developmental Principle of Formative Evaluation}

The ultimate purpose of higher vocational English teaching evaluation system is not to appraise the strengths and weaknesses as well as the advantages and disadvantages of students; instead, its ultimate purpose is to help the teachers find the approaches to enhance teaching quality and the students promote their self-abilities, which can be satisfied by the formative evaluation. The teacher's evaluation on student's English study should focus on the student's participation degree during the learning process, the interest in learning English and comprehension for different cultures instead of restricting to student's exam results. In the English language teaching of higher vocational schools, the formative evaluation should be the students' learning motivations so as to arouse the students' learning interests, give full play to subjective initiative, deepen the students' understanding of different cultures and improve the English conversation abilities of students in higher vocational colleges.

\section{Open Principle of Formative Evaluation}

The formative evaluation of high vocational teaching is characterized by openness and thus the English teachers and students in higher vocational colleges should abide by open principle during the evaluation process, that is to say, the evaluation methods of teachers and students in vocational schools, the selection of evaluation subjects and the evaluation results should be open; in order to realize the openness of evaluation, the English teachers in higher vocational colleges should create the relaxed and comfortable environment according to the students' characteristics so that the students dare to evaluate openly. [7]

\section{CONCLUSIONS}

The educational objective of higher vocational schools is to cultivate higher application-orientated talents. Through the English courses, the students' literacy knowledge is improved and the communication ability is also cultivated. Since the current evaluation system is divorced from educational reality, the formative evaluation method should be the development direction of educational evaluation in our country. The formative evaluation emphasizes the principal status of students and takes the actual demands of students into 
consideration, thus fully representing the people-oriented education thought.

\section{REFERENCES}

[1] Wang Lin. Application of Formative Evaluation in Higher Vocational English Teaching [J]. Journal of Shanxi Institute of Economic Management, 2011,19(4):107-110.

[2] Jin Yan. An Analysis on Application of Formative Evaluation in Higher Vocational English Teaching [J]. Campus English (first third of a month ),2014,(10):94-94,95.

[3] Zhang Caiyu, Li Qiang, Jiang Xiaojing et al. The Construction Principle and Method of Formative Evaluation in Higher Vocational English Teaching [J].Management \& Technology of SME, 2014,(7):248-249.

[4] Li Xiaohong, Yu Yihui, Ding Zhiming, Zhang Fengzhen, Jin Yihua. On formative evaluation and English Teaching in higher vocational institutes of China[J] Jounal of Chong Qing Vocatioanal Institutes , 2007 (03).

[5] Hu Jinju. On formative evaluation and College English Teaching[J] Journal of Huabei College of Hydraulic and Electric Engineering. 2003 (01).

[6] Sheng Xiangjun. Reaearch and Application of formative evaluation in English Teaching of Higher Vocational institutes[J]Academic Marketplace, 2005(05).

[7] Wang Hua, Fu Changhong. A review of the Application of Formative Assessment in Foreign language teaching[J]Foreign Language World. 2006(04). 